\title{
Reciprocality in Papuan Malay
}

\author{
YUSUF SAWAKI
}

\begin{abstract}
Reciprocality, also known as reciprocal situation or reciprocal constructions, constitutes an expression which describes both the forms and meaning of an activity embodying a mutual relation. Papuan Malay, a pidginized lingua franca in Western New Guinea, has three types of constructions expressing reciprocality: lexical reciprocals, prototypical syntactic reciprocals with the baku construction, and syntactic reciprocals with the discontinuous satu...satu construction. Some additional constructions are considered to be reciprocal-like. These reciprocal constructions vary in their argument structure and valence operations. In argument structure, most constructions allow two kinds of argument structure: Type 1, which takes only a subject argument, and Type 2, which takes both a subject and object, and follows the basic SVO word order. However, the object in the Type 2 construction becomes oblique-like, indicating reduced transitivity in order to accommodate the concept of mutual relation. In valence operations, reciprocals can undergo both valence decreasing and valence increasing operations. In addition, some reciprocal constructions require subject and object to be syntactically retained, even though semantically they represent the same agent-patient/goal mutual relation.
\end{abstract}

KEYWORDS

Reciprocality; mutual relation; argument structure; valence operations; Papuan Malay.

YUSUF SAWAKI took his PhD degree at the Australian National University with a grammar of the Austronesian language, Wooi, spoken on Yapen Island in the province of Papua. He is the Director of Center for Endangered Languages Documentation (CELD) and the Head of Papuan Language and Culture Center, University of Papua, Manokwari. He is currently leading the ELDP project (MDP 0372), "Documenting Konda and Kais: two endangered and lesser-known Trans-New Guinea languages of the Southern Bird's Head of New Guinea". He is the co-initiator of the only international linguistic conference in Papua, the Workshop of the Languages of Papua (WLP) since 2007, with Professor David Gil (MPI Jena, Germany), Professor Nicholas Evans (ANU, Canberra, Australia). Yusuf Sawaki can be contacted at: ysawaki@fulbrightmail.org.

(C) 2021 Faculty of Humanities, Universitas Indonesia

YUSUF SAWAKI | DOI: 110.17510/wacana.v22i2.959. 


\section{INTRODUCTION ${ }^{1}$}

Reciprocality has become a focus of the recent linguistic work in different schools of linguistics. Both the semantic and syntactic structures, within individual languages and cross-linguistically, have been the focus of a number of studies (for example, Ash Asudeh 1998; Nicholas Evans et al. 2011; Peter Hurst 2006; Ekkehard König and Voker Gast 2008; Vladimir Nedjalkov 2007; Rachel Nordlinger 2008). Many typologists also investigate reciprocality beyond the linguistic domain, in the context of social cognition in the world's languages (Evans 2006; Evans et al. 2011; König and Gast 2008). Consequently, various terms have been used to indicate reciprocality - reciprocal situation, reciprocal event, reciprocal relation, reciprocal construction, reciprocal marker, and reciprocal predicate (Martin Haspelmath 2007; Nedjalkov 2007). These terms are used interchangeably for both semantic and structural expressions of reciprocality. In this article, I use "reciprocal constructions" to describe regular syntactic constructions which represent reciprocal events, as well as their semantic content (see Evans 2008). Clauses such as "I pushed John" and "John pushed me" are regular expressions in English which can be semantically integrated into a single clause "John and I pushed each other". This construction is principally said to be a reciprocal event which includes a two-place predicate explicating two arguments in a mutual relation (Haspelmath 2007), each behaving as semantic agent and patient simultaneously when performing the action together towards each other as part of a single, complex reciprocal event.

This article aims to describe reciprocal constructions in Papuan Malay. The term "reciprocal construction" refers to structural/syntactic basis of reciprocality in Papuan Malay grammar. Although my focus of discussion is on the structural level, I shall also deal with other semantic expressions which contribute to the understanding of reciprocality in Papuan Malay.

On the whole, Papuan Malay applies different types of reciprocal constructions which represent different semantic expressions of the relations between arguments. The choice of construction depends on the tightness of the semantic relationship being described.

\section{Papuan Malay: A historical and typological overview}

Papuan Malay is the pidginized Malay spoken as a lingua franca in the western part of New Guinea, in the Indonesian provinces of Papua and West Papua (Danilyn Rutherford 2005). The use of the language is relatively new in the region but it has at least 200 years of history behind its presence in New Guinea (Mark Donohue 2011; Scott Paauw 2008). It was originally introduced along an ancient trading route between New Guinea and other neighbours to the west and reinforced by the initial establishment of the Dutch colonial administration in Papua in 1828 (Mark Donohue and Yusuf Sawaki 2007). Since then, Malay

\footnotetext{
${ }^{1}$ I would like to express my appreciation of Emily Gasser and Laura Arnold for proofreading
} and reviewing the first version of this article, but I am still responsible for all its deficiencies. 
has taken on the role of a lingua franca. It has spread through most regions of Indonesian New Guinea, but especially the northern coast of the Bird's Head and around Cenderawasih Bay (formerly Geelvink Baai) as well as along the southwest coast around the Kaimana and Fakfak regions, where it is now used extensively. The first records of Malay used in New Guinea among Biak people were made by Antonie Haga (1884). However, Papuan Malay might have been used long before that along the southwest coast of New Guinea on the old trading route between Onin and Seram Laut. This despite the fact that in that region, the Onin language, a mixture of Malay and local languages spoken along the coasts of the Bomberai Peninsula (W. Seiler 1983; John Conroy 2013: 15), has also been used as a special trade lingua franca.

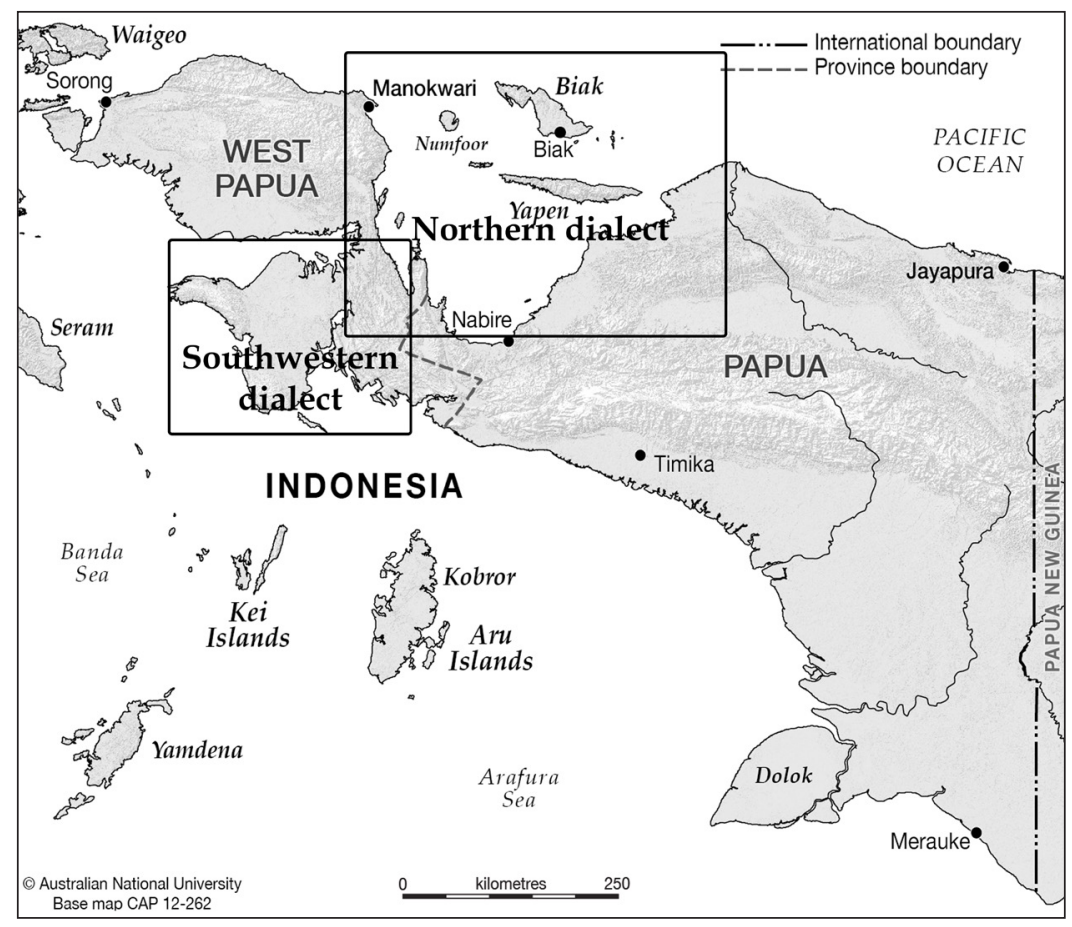

Map 1. The Papuan Malay-speaking area in New Guinea and the two dialect variations discussed in this article. (Courtesy of Australian National University).

Historically, different parts of New Guinea established various sociocultural and economic linkages to different parts of outside world. The linkage between western New Guinea and outsiders can be seen in Conroy (2013). As Papuan Malay has long been in contact with other languages, in particular Austronesian languages in the Papua region, under influence of these languages, it has undergone restructuring in terms of the structural building blocks, although it still retains many Malay features (see Paul van Velzen 1995; Donohue and Sawaki 2007; Paauw 2008; Donohue 2011; Sukardi Gau 2011; Yusuf Sawaki and Sara Karubaba 2012; Angela Kluge 2014). Sociolinguistically, Papuan Malay has several regional dialects (see Donohue and 
Sawaki 2007; Kluge 2014). For the purpose of this article, I focus on the northern dialect, my native dialect, of Papuan Malay (see Map 1).

Typologically, Papuan Malay uses the word order SV/AVP in the basic clause, as in (1a) and (1b).

(1) a. Jon de=tidur di sa=pu=ruma

John 3SG-sleep at 1SG=POSS=house

'John sleeps/slept in my house.'

b. Agus don=dorong tong ${ }^{2}$ tadi.

Agus 3PL=push 1PL just.now

'Agus and associates pushed us just now.'

Its verbal morphology reflects the features of regional Austronesian languages in which the pronominal subject marker attaches to the verb as a proclitic. Bound pronouns can also mark possessors when prefixed to the possessive marker; while objects are expressed by syntactically free pronouns or NPs, as shown above. Free pronouns can also function as the subject of a siapa 'who' question (see Donohue and Sawaki 2007; Sawaki and Karubaba 2012).

Papuan Malay has an accusative alignment system in which subject and agent are marked identically as opposed to object or patient. Passive constructions can promote patient, benefactive, goal, and theme in the subject position. However, the degree of animacy affects the accessibility of participants to promotion in passive sentences. Human and animate objects are more accessible in passive constructions than their inanimate counterparts. Papuan Malay also allows object alternations with indirect objects in ditransitive constructions. In complex predicates such as depictive, causative, resultative, instrumental, and serial verb constructions, co-referenced argument sharing is common.

\section{RECIPROCALS SEMANTIC AND STRUCTURAL CONCEPTS}

Reciprocal relations are shown through syntactic structure, which varies by language. Reciprocals are two-place predicates (Nedjalkov 2007) in which two participants are involved in an identical or parallel relation. The identical or parallel relation refers to a mutual relation (Haspelmath 2007), so that each

\footnotetext{
${ }^{2}$ Papuan Malay has two types of personal pronouns, namely free and bound pronouns (Donohue and Sawaki 2007). The free pronouns function grammatically as the object argument, the inclusory pronoun modifying the head noun in a noun phrase, and as an answer (predicate) to a question. On the other hand, the bound pronouns function as the proclitic-subject in both the verbal predicate or in non-verbal predicates. Beside, they also have alternate bound forms phonetically as the native speakers of Papuan Malay alternatively use tong ton ten for the first person plural and dong don den for the third person plural. The first alternate form is mainly used for the object pronoun or when the pronoun is positioned at the final position of a sentence. The other two alternate forms are used alsewhere. They derived from the free forms kitong ketong katong for the first person plural and dorang for the third person plural. These alternate forms could also reveal dialectal variations.
} 
of the two participants semantically functions as both agent and patient in a same act in the same time (Nedjalkov 2007; Asudeh 1998; Hurst 2012). Note that, by definition, predicates denoting relational situations with only one or more than two participant(s) cannot be considered to be reciprocal, or are at least less reciprocal (Haspelmath 2007). As relational situations, reciprocals can be semantically extended depending on extralinguistic relationships such as friendship, animosity, partnership, togetherness, and other social relations. Languages employ different reciprocal constructions to represent these various extralinguistic facts. Nedjalkov (2007: 6) states that reciprocal meaning types include "to/of/against/from/with/[...] each other", highlighting situations in which two participants are within the following parameters:

a. They are in the identical reverse relations and have the same semantic content as in (2).

(2) John and Bill are friends.

b. They perform two identical semantic roles (for instance, of agent and patient) each as in (3).

(3) John and Bill hit each other (that is, John hits Bill and Bill hits John).

The parameters limit the semantic meaning of reciprocal constructions to only two participants in the prototypical reciprocal. Other relations are possible but less prototypical. For example, the situation can be extended to a plural set of more than two participants, such as in English sentences in (4), (5), and (6).

(4) The children hit each other.

(5) Simon, Bill, and John killed each other.

(6) People pushed each other.

The relations established with a collective plural participant such as in (4), the three participants in (5), and indefinite plural in (6) are somewhat different from the prototypical reciprocal relation indicated in the parameters above. However, many languages treat these relational situations using identical reciprocal marking.

Typologically, there are four main types of reciprocal constructions applied in languages, namely lexical, morphological, syntactic, and compositional reciprocals.

a. Lexical reciprocals: In many languages, lexical words, namely verbs, carry reciprocal meaning inside their stem/root, such as in the English verbs to argue, to fight, and to meet, and in English nouns such as brother, partner, colleague, friend, couple, et cetera (see Haspelmath 2007). They semantically determine (at least) two participants are involved in the relational events. 
b. Morphological reciprocals: In languages such as Indonesian, there is a morpheme attaching to the verb root to add semantic meaning of reciprocality. For instance, the prefix ber-in the morphological verb bertemu 'to meet each other' or berkelahi 'to fight with each other' carries the meaning of reciprocal to the predicate as in (7) and (8).

(7) Agus dan Amir ber-kelahi

Agus and Amir ACT-fight

'Agus and Amir fought with each other.'

(8) Budi dan Yuli ber-temu di pasar

Budi and Yuli ACT-meet at market

'Budi and Yuli met each other at the market.'

c. Syntactic reciprocals: This type occurs in languages in which there is a lexical item which carries the semantic feature of reciprocality for the whole construction. The lexical item usually brings a reciprocal relation to the verb it modifies in a compositional relation, as in Indonesian saling 'REC'.

(9) Yani dan Joko saling me-marah-i

Yani and Joko REC ACT-angry-APPL

'Yani and Joko are angry with each other.'

d. Compositional reciprocal. The compositional reciprocal is a construction in which the reciprocal meaning derives from the whole construction, regardless of the presence of the reciprocal marker. In Wooi (Sawaki 2016: 312), an Austronesian language of New Guinea, the meaning of reciprocality comes from the whole construction as in (10) and (11); no overt reciprocal marker is present.

(10)

Humung haru na ramdempe
/hu-r-mung/
3DU-DU-fight 3DU LOC yesterday

'They two fought each other yesterday.' (expected event)

Note that sentence (10) cannot be interpreted as the two of them fought against someone else as, the prefixed-subject $h u$ - '3DU' on the verb -mung 'fight', and the object haru '3DU' co-references. This is a case of the compositional reciprocal.

Another compositional reciprocal is constructed by having a reflexive marker indicate reciprocality. In Wooi (Sawaki 2016), a reciprocal expression which is used to describe an unexpected event is formed with the reflexive marker vaveri 'REFL' as in (11). The argument structure (subject and object) follows the same pattern in the compositional reciprocal.

(11) hurariu vaveri haru
/hu-r-ariu/
3DU-DU-meet REFL 3DU

'They two met each other.' (unexpected event) 
Types B, C, and D are commonly referred to as grammatical reciprocals (Nedjalkov 2007; Haspelmath 2007) because they make use of certain kinds of grammatical elements such as morphemes (prefixes or suffixes), syntactic markers, and syntactic constructions to construct reciprocal relations.

\section{Reciprocal constructions in Papuan Malay}

Papuan Malay has a fairly wide range of reciprocal events represented in the language by various constructions. These constructions fall into different categories, both semantic and structural. Grammatically, reciprocals in Papuan Malay include lexical, morphological, and syntactic constructions: the lexical reciprocals, the baku constructions and the discontinuous reciprocal satu...satu constructions. There are also some constructions categorized as reciprocal-like constructions such as the adverbial reciprocal sama-sama, subject-oriented, object-oriented mutual relations, and possessor-oriented mutual relations. The reciprocal-like constructions are considered less reciprocal than the prototypical examples and can permit a reciprocal interpretation in different contexts.

\subsection{LEXICAL RECIPROCALS}

There are some lexical verbs in Papuan Malay expressing a mutual relation between two participants in which the meaning of reciprocal is expressed within the verb itself, as in (12), (13), and (14).

(12) $\quad$ Sa=deng Andi ten=dwa=bakalai

1SG=with Andy 1PL=two=fight

'Andy and I fought (each other).'

(13) Den $=d w a=k e t e m u$ di jalan tadi

$3 \mathrm{PL}=\mathrm{two}=$ meet at street just.now

'They (two) met each other at the street just now.'

(14) Jon de=deng Andi sodara

John 3SG=COM Andy sibling

‘John and Andy are siblings.'

The verbs bakalai 'fight' and ketemu 'meet', and the noun sodara 'sibling' are lexical items which have a semantically intrinsic reciprocal meaning - the event, situation or state entails a mutual relation between participants. When the verb bakalai 'fight' is used as in (12), it can only be interpreted as 'Andy and I fought each other' but not 'Andy and I fought together against someone else'. These predicates require two participants in mutual relation as agent and patient/ goal, although both arguments are expressed in the subject position. The noun sodara 'sibling' in (14) indicates brotherhood, a symmetrical family relation.

Lexical verbs and nouns which semantically code a mutual relation can be used with the baku construction, which is the prototypical reciprocal construction in Papuan Malay shown in (15), (16), and (17). 
(15) Sa=deng Andi=de $e^{3} \quad$ baku=bakalai

1SG=COM Andy=3SG REC=fight

'Andy and I fought each other.'

(16) Tadi ton=dwa baku=ketemu

just.now 1PL=two REC=meet

'Just now, we met each other.'

(17) Jon de=deng Andi baku=sodara

John 3SG=COM Andy REC=sibling

'John and Andy are (each other's) siblings.'

The prototypical construction in (15), (16), and (17) will be described in more detail below.

\subsection{PROTOTYPICAL RECIPROCAL WITH THE BAKU CONSTRUCTION}

The baku construction is the prototypical reciprocal construction in a number of varieties of Eastern Indonesian Malay, including Kupang Malay, Ambon Malay, Manado Malay, Ternate Malay, and Papuan Malay (B.H.J. Litamahuputty 2012; Paauw 2008; Ken Stark and Kyle Letinis 1996; Hein Steinhauer 1983; Don van Minde 1997; and Maxi Wantalangi 1993; David J. Prentice 1994). Papuan Malay in particular tends to use it widely in its grammar (Kluge 2014; Sawaki and Karubaba 2012). In the baku construction, the reciprocal structure is reflected in the phrasal structure, which consists of a verbal phrase, noun phrase, or adverbial phrase including $b a k u$ 'REC' as the reciprocal element and a verb/noun/adverb which indicates the event. Hence, baku 'REC' combines with a verb form for a reciprocal event. It can be illustrated in the following structures:

$$
\begin{aligned}
& \text { Type 1: [[A COM B } \left.]_{\text {SUBJ }}[b a k u \text { 'REC' + VERB/NOUN/ADVERB }]_{\text {REC. EVENT }}\right] \\
& \text { Type 2: [[A } \left.]_{\text {SUBJ }}[b a k u \text { 'REC' + VERB/NOUN/ADVERB }]_{\text {REC EVENT }}[\mathrm{COM} \mathrm{B}]_{\mathrm{OBJ}}\right]
\end{aligned}
$$

\footnotetext{
${ }^{3}$ Note that the marked third person singular $=d e$ 'SG' in (15) and the unmarked counterpart in (17) are possible constructions which are grammatically acceptable in Papuan Malay. The marker shows both persons in the subject position are individual entities linked by the comitative deng ' $\mathrm{COM}^{\prime}$ ' as in (a). It is also possible to have a construction in which both persons are seen as the subject of the collective noun by having the associative plural marking ton $=d w a$ ' $1 \mathrm{PL}=\mathrm{two}$ ' proclitics to the verb as in (b).
}

(a) Jon=de deng Andi=de don=dwa=baku=sodara John=3SG COM Andi=3SG 3PL=two=REC=sibling

'John and Andi are brothers to each other.'

(b) Sa=deng Andi ton=dwa=baku=bakalai 1SG=COM Andi $1 \mathrm{PL}=$ two $=$ REC $=$ fight

'I and Andi fought each other.' 
Types 1 and 2 differ in the placement of the second participant in the clause. The prototypical reciprocal construction is the Type 1 construction. Its sole requirement is that the subject precedes the reciprocal verbal predicate. The subject is filled by both the semantic agent and patient/goal/recipient to indicate a mutual relation. The mutual relation is indicated by the comitative marker deng ' $\mathrm{COM}^{\prime}$ ' triggering the similar semantic role of the subject and the object. This is illustrated in (18) and (19).

Agus deng Jon den=dwa baku=mara

Agus COM John 3PL=two REC=angry

'Agus and John are angry with each other.'

(19) Yakoba de=deng Eni den-dwa=baku=panggil

Yakoba $3 \mathrm{SG}=\mathrm{COM}$ Eni 3PL-two=REC=call

'Yakoba and Eni called each other.'

Syntactically, the reciprocal marker baku 'REC' in the phrase has two grammatical functions. It functions as the verbal modifier to indicate a reciprocal event and it also triggers argument structure. As the reciprocal marker, baku is syntactically dependent on a verb, a noun or an adverb which it modifies. Note that not all verbs, nouns, and adverbs can be modified by the reciprocal marker baku, only verbs, nouns, or adverbs which show strong mutual relations in the transitivity concept. Transitivity determines if the predicate is at least a two-place predicate or higher in the reciprocal hierarchy. Verbs like $p u k u l$ 'hit', dorong 'push', and panggil 'call' are accessible to reciprocal constructions.

\section{(20) Piter deng orang itu den-dwa=baku=pukul \\ Piter COM man that $3 \mathrm{PL}=\mathrm{two}=\mathrm{REC}=$ hit \\ 'Peter and that man hit each other.'}

Type 2 reciprocal construction deals with different argument structure of subject and object. Subject and object will follow the basic word order, that is, SVO in Papuan Malay. However, the object argument is treated as an obliquelike argument preceded by the preposition deng 'COM'. Semantically, the object with preposition functions to reduce the transitivity of patient-object into new semantic role as an agent-patient object. Therefore, the object in the Type 2 construction is different from the prototypical transitive clause in Papua Malay in which the object is definitely a patient, as in (21); whereas, Sentences (22) and (23) are reciprocal constructions.
(21) Minggus de=dorong Ronal dia
Minggus 3SG=push Ronald 3SG
'Minggus pushed Ronald.' 
(22) Minggus de=baku=dorong deng Ronal dia

Minggus 3SG=REC=push COM Ronald 3SG

'Minggus and Ronald pushed each other.'

(23) Meri de=baku=suka deng Boas dia

Meri 3SG=REC=like COM Boas 3SG

'Meri and Boas like each other.'

In expressing reciprocal meaning, a construction from which the oblique marker deng 'COM' is deleted will produce an ungrammatical and unaccepatable sentence structure, as in (24).

*Meri de=baku=suka Boas dia

Meri $3 \mathrm{SG}=\mathrm{REC}=$ like Boas he

Semantically, Type 1 and Type 2 differ slightly in who initiates an action. In Type 1, both the agent and the patient/goal/recipient in the subject position initiate the action and they perform the action in an equivalent and parallel relation. In Type 2, the subject is always considered to be the starting-point in initiating the act and the object responds to it in an equivalent way in order to establish the mutual relation. To show the mutual action performed by the object, the object appears in an oblique position as a consequence of the decreased transitivity which establishes the mutual relation, as in (22) and (23).

Type 1 constructions can also be used in a clause with a nominal predicate, in which the head of the predicate is a noun phrase. The nouns which can be modified by the reciprocal marker $b a k u$ 'REC' are those relating to family or friendship relations such as sibling, family, friend, and acquaintance. These types of nouns in Papuan Malay are more transitive than other nouns. Hence, they are accessible to a reciprocal event, as in (25) and (26).

$$
\begin{aligned}
& \mathrm{S} a=\text { deng } \quad \text { de } \quad \text { ten }=\text { dwa }=\text { baku=sodara } \\
& 1 \mathrm{SG}=\mathrm{COM} 3 \mathrm{SG} 1 \mathrm{PL}=\mathrm{two}=\mathrm{REC}=\text { sibling } \\
& \text { 'He and I are siblings (of each other).' }
\end{aligned}
$$

(26) Isak de=deng Ronal dong=baku=teman

Isak $3 \mathrm{SG}=\mathrm{COM}$ Ronald $3 \mathrm{PL}=\mathrm{REC}=$ friend

'Isak and Ronald are friends (of each other).'

Sentence (25) can be paraphrased as "I am a sibling of him and he is a sibling of me". Likewise, example (26) can be paraphrased as "Isak is a friend of Ronald's and Ronald is a friend of Isak's".

Type 2 reciprocals are also accessible with a nominal predicate. The construction in the nominal predicate is similar to that of the verbal predicate. The sentence in (25) above could have the alternate construction as in (27). 
(27)

$$
\begin{aligned}
& \text { Sa=baku=sodara deng dia } \\
& \text { 1SG=REC=sibling COM him/her }
\end{aligned}
$$

'He and I are siblings of each other.'

Unlike sentences with a verbal predicate, Type 2 constructions with nominal predicates are not different in meaning from Type 1 . In both cases, the subject is considered as the starting-point to show the family relation with the object.

The Type 1 construction also acts to modify adverbs. Adverbs mainly function to modify a verb in terms of manner or situation. Therefore, the semantic relation between an adverb and a verb is clearly an eventual relation - a verb being the source of action and the adverb the modifier of the action. However, a mutual relation indicating reciprocality is established between subject and adverbial phrases. Sentences (28) and (29) show that the adverbial reciprocals co-refer to the participants in the subject position, so the situations qualify as having a mutual relation.

(28) Melki de=deng Yani den $=d w a=d u d u k$ baku=dekat

Melki 3SG=COM Yani 3PL=two=sit REC=close

'Melki and Yani sat close to each other.'

$$
\begin{aligned}
& \text { Yanti de=deng Rut den=dwa=jalan baku=sebla } \\
& \text { Yanti de=COM Ruth 3PL=two=walk REC=beside } \\
& \text { 'Yanti and Ruth walked next to each other.' }
\end{aligned}
$$

Adverbial reciprocals are also accessible to Type 2 constructions like those found in verbal and nominal reciprocals. Consider sentences (30) and (31), Type 2 distinguishes subject and object in the grammatical relation.

$$
\begin{aligned}
& \text { Melki de=duduk baku=dekat deng Yani dia } \\
& \text { Melki 3SG=sit REC=close COM Yani 3SG }
\end{aligned}
$$

'Melki and Yani sat close to each other.'

Yanti de=jalan baku sebla deng Rut dia

Yanti 3SG=walk REC beside COM Ruth 3SG

'Yanti and Ruth walked next to each other.'

Semantically, the subject is the projecting point which indicates the mutual relation. In (30), Melki as the subject is seen as the projecting point of the mutual relation with the object, Yani. The mutual relation is shown by the reciprocal adverb rather than the object argument itself.

Another prototypical construction which is commonly used in Papuan Malay is the competitive reciprocal construction. This construction is restricted to an expression in which two participants are facing each other in competition to each other. Here, the competitive marker taru 'COMP' is used within the baku construction, as in (32) and (33). 
(32) Orang itu ten=dwa=baku=taru=makan

Man that $1 \mathrm{PL}=\mathrm{two}=\mathrm{REC}=\mathrm{COMP}=\mathrm{eat}$

'That man and I competed against each other to eat.'

(33) Sa=deng de baku=taru=lari

$1 S G=\mathrm{COM}$ 3SG $\mathrm{REC}=\mathrm{COMP}=\mathrm{run}$

'I and he competed against each other to run.'

Unlike other baku constructions, Sentences (32) and (33) show that the construction is well constructed with intransitive verbs such as makan 'eat' and lari 'run' which are less transitive and semantically do not show physical contact between participants. Using taru ' $\mathrm{COMP}^{\prime}$ ' with a transitive verb such as pukul 'hit' or dorong 'push' will project a different meaning such that the subject (as the agent) competes in doing the action with an object (patient) as in (34).

(34) Agus de=deng Yunus baku=taru=pukul orang itu. Agus 3SG=COM Yunus $\mathrm{REC}=\mathrm{COMP}=$ hit man that

'Agus and Yunus are competing to hit that man.'

In (34), the subjects, Agus and Yunus, are in a mutual relation as competitors in performing the act of hitting the object, that man. The subjects and the object do not show such a relation; instead their relation is as agent and patient. In order to have a reciprocal meaning between subject and object, the reciprocal marker baku 'REC' is doubled and the object takes the comitative preposition deng ' $\mathrm{COM}^{\prime}$ ' as in (35).

(35) Agus de=deng Yunus baku=taru baku=pukul deng orang itu Agus $3 \mathrm{SG}=\mathrm{COM}$ Yunus $\mathrm{REC}=\mathrm{COMP}$ REC $=$ hit $\mathrm{COM}$ man that

'Agus and Yunus compete with that man to hit each other.'

Simply, Sentence (35) means that Agus and Yunus on the one side are competing with that man on the other side to hit each other. The sentence cannot be interpreted as Agus competing with Yunus in hitting that man. The Type 2 construction can also be applied to the competitive reciprocal construction, as in (36) and (37).

(36) Orang itu de=baku=taru=makan deng saya

man that $3 S G=R E C=C O M P=$ eat $C O M$ me

'That man and I competed against each other to eat.'

(37) Sa=baku=taru=lari deng dia

1SG=REC $=$ COMP=run COM him/her

'I and he competed against each other to run.'

As the prototypical Type 1 baku construction in the verbal predicate, the competitive reciprocal construction carries the same meaning as that of the verbal predicate. The subject is always considered to be the starting-point in 
initiating the competitive act towards the object in an identical and mutual relation.

All alternate constructions of the prototypical reciprocals indicate that the object is syntactically introduced into the construction and is categorized as an increased-valence operation. This is described more fully in the section about valence-increasing operations below.

\subsection{RECIPROCAL WITH THE SATU...SATU CONSTRUCTION}

Papuan Malay also has another reciprocal construction with satu...satu. The satu...satu construction can occur with both verbs and nouns. In the first case, this construction occurs with transitive verbs and involves their prototypical participants, that is subject and object. As semantically the construction represents unspecified participants, it requires the participants first be introduced to the discourse, as in (38) and (39).

$$
\begin{aligned}
& \text { Ade kaka den=dwa ni, satu sayang satu } \\
& \text { sibling 3PL=two FOC one love one } \\
& \text { 'The two siblings love each other.' }
\end{aligned}
$$

(39) Den=dwa=badiribaru satu pukul satu

$3 \mathrm{PL}=\mathrm{two}=$ stand then one hit one

'They two stood up and then they two hit each other.'

In (38), the satu...satu construction in the clause co-references the topic participants ade kaka dong=dwa at the beginning of the sentence. Similarly, in (39) the satu...satu construction co-references the plural subject dong= '3PL-' in the first clause. These arguments reflect subject and object in transitive verbs but, semantically, they are mutually related as they both perform the same action towards each other. Like the baku construction above, the satu...satu construction has the possibility to form a Type 2 construction, as in (40).

(40) Dong=dwa itu, satu baku=pukul deng yang satu

3PL=two that one REC=hit COM REL one

'As for those two, they hit each other.'

\section{RECIPROCAL-LIKE CONSTRUCTIONS}

In Papuan Malay, there are constructions which semantically demonstrate a mutual relation between participants involved in an act. However, they are not categorized as true reciprocal constructions by the definition given above. Consequently, I treat them as reciprocal-like constructions. Reciprocal-like constructions show two main features. Firstly, they do not meet the structural criteria of reciprocal constructions as defined above. Secondly, nevertheless, they do still have the semantic expression of mutual relation in which two (or more) participants act on each other or on the particular object in mutual relation. The following semantic-syntactic expressions fall into reciprocal-like constructions. 


\subsection{SUBJECT-ORIENTED AND OBJECT-ORIENTED MUTUAL RELATIONS}

There are two constructions in which mutual relation is expressed by reduplicated numerals. This feature always refers to the noun functioning as subject or object. I refer these constructions as subject-oriented and objectoriented mutual relations. The object-oriented mutual relation indicates the mutual relation between the object and the indirect object. The reduplicated form satu-satu 'RED-one' here specifies the number of the direct object which is given distributively to the indirect object, as in (41).

$$
\begin{aligned}
& \text { (41) Dong=pu=bapa de=kase don=dwa ruma satu-satu } \\
& \text { 3PL=POSS=father } 3 \mathrm{SG}=\text { give } 3 \mathrm{PL}=\mathrm{two} \text { house } \\
& \text { 'ThDeir father gave each of them (two) a house.' }
\end{aligned}
$$

The satu-satu construction means that both members given in the indirect object dong $=d w a$ ' $3 \mathrm{PL}=$ two' gets a house each. Furthermore, the numeral reduplication can also be used for other numbers as well as such $d w a-d w a$, tiga-tiga, and so forth.

$$
\begin{aligned}
& \text { (42) Don=dwa dapa ruma tiga-tiga } \\
& \text { 3PL=two get house RED-three } \\
& \text { 'The two of them got three houses each.' }
\end{aligned}
$$

The subject-oriented reciprocal identifies a mutual relation between individuals in a collective plural subject in relation to the object in the clause, as in (43).

$$
\begin{array}{lllll}
\text { Don }=d w a=d w a & \text { dapa } & \text { ruma } & \text { dari } & \text { dong=pu=bapa } \\
\text { 3PL=RED=two } & \text { get } & \text { house } & \text { from } & \text { 3PL-POSS-father }
\end{array}
$$

'They (two) got one house each from their father.'

In (43), the clause don=dwa=dwa dapa ruma means the two individuals in the collective (here dual) subject get one house each. The dual subject receives the reciprocal sense in which two participants are benefited by the act of their father in a mutual relation. Furthermore, the construction can also be applied to a construction in which subject-oriented and object-oriented relations take place in the same time as in (44).

$$
\begin{aligned}
& \text { (44) Don=dwa-dwa dapa ruma dwa-dwa } \\
& \text { 3PL=RED-two get house RED-two } \\
& \text { 'They (two) got two houses each.' }
\end{aligned}
$$

In (44), the collective subject don=dwa-dwa 'they two' has a mutual relation between themselves and the object ruma dwa-dwa 'two houses', indicating the number of houses given to the subject as evidence of mutual relation.

The reduplicated numeral form can function as the subject without any overt head nouns or pronouns. It is also a subject-oriented reciprocal, similar to 
(43) and (44). In (45), the reduplicated number dwa-dwa refers to the collective (dual) subject.
Dwa-dwa
su=dapa ruma dar
don $=p u=b a p a$
RED-two PERF=get house from 3PL-POSS-father
'Each of the two has got a house from their father.'

\subsection{POSSESSOR-ORIENTED MUTUAL RELATIONS}

In the possessive construction, a reduplicated number can be used to indicate the reciprocal-sense relation of the possessors. The possessors must consist of more than one individual. The possessor satu=satu in (46) shows that there are two individual possessors who have identical mutual relation with the possessee.

$$
\begin{array}{lllll}
\text { Satu-satu=pu=kursi } & \text { to, } & \text { jadi } & \text { jang } & \text { mara-mara } \\
\text { RED-one=POSS=chair } & \text { PART } & \text { so } & \text { NEG.IMP } & \text { RED-angry }
\end{array}
$$

'Each of you has a chair, so don't be angry with each other.'

In (46), satu-satu 'RED-one' represents two individual persons who have one kursi 'one chair' each in the possessor-possessee mutual relation. The reciprocal-sense relation occurs in the subject and in a one-to-one relation with the object. Furthermore, the action mara-mara 'angry' is also in mutual relation between the two individual persons represented in the satu=satu expression.

The possessor can be expressed with collective plural individuals - three or more, to describe mutual relations. For instance, if the possessor is dwa-dwa 'two-two', the meaning is that there are two individuals, and the mutual relation is expressed by the reduplicated number of the collective possessor as in (47).

$$
\begin{aligned}
& \text { Dwa-dwa=pu=kursi to jadi jang } \quad \text { mara-mara } \\
& \text { RED-two=POSS=chair PART so NEG.IMP RED-angry } \\
& \text { 'You two have a chair each, so don't be angry with each other.' }
\end{aligned}
$$

In (47), the possessor $d w a-d w a$ 'RED-two' identifies the subject possessor as a collective noun/ pronoun, that is, a dual possessor subject, of whom each has a mutual relation with the possessee - in other words, they have one chair each.

To sum up, satu-satu 'RED-one' reciprocal is a possessor subject-oriented reciprocal which semantically shows a one-one mutual relation between the plural subject and object. In a construction which has more than one possessor subject, such as dwa-dwa, tiga-tiga, the mutual relation semantically shows the collective relation of the dual, trial or plural subject with the object.

\subsection{THE MUTUAL EXPRESSION SAMA-SAMA}

There are constructions expressed by the reciprocal-like adverb sama-sama 'RED-together' which implies togetherness. Sama-sama conveys a situation in which two participants are mutually involved in the same identical event. For instance, sama-sama makan 'eat together' means a group of people (we, 
you, and they) are involved together in the action of eating. Grammatically, sama-sama can function as a subject, a predicate, and an adverbial clause. Note that the construction is not merely a prototypical reciprocal construction but also expresses a mutual relation as a reciprocal does.

As a subject, sama-sama can stand without a head noun in a clause as in (48). The subject sama-sama indicates that the subject is a plural subject and it semantically defines the mutual relation between individuals of the plural subject.

(48) Sama-sama suka makan ikan
RED-together like eat fish
'(we/you/they) Altogether like to eat fish.'

When a clause has a head noun, sama-sama functions as a modifier of the nominal subject, as in (49). The mutual relation between individuals of the plural subject is similar to that of (48).

(49) Dong=sama-sama suka makan ikan 3PL=RED-together like eat fish

'They altogether like to eat fish.'

Sama-sama can also function as a predicate of a clause. As a predicate, it can be an intransitive predicate in which it has only a subject, within which the reciprocal relation occurs as in 50).
(50) Jon de=deng Agus den=dwa=sama-sama tadi di sini John 3SG=COM Agus 3PL=two=RED-together just.now LOC here 'John and Agus were together here just now.'

The example in (50) is also a subject-oriented reciprocal in which the reciprocal event occurs within the plural subject. However, the reciprocal event can also be indicated by the mutual relation between subject and object in a transitive predicate enacted by the reciprocal sama-sama, as in (51).

$\begin{array}{llll}\text { (51) Tadi } \quad \text { ton=sama-sama } & (\text { deng) } & \text { dia } \\ \text { just.now } & \text { 1PL=RED-together } & \text { (COM) } & \text { 3SG } \\ \text { 'We were together with him just now.' } & \end{array}$

Sama-sama can also function as a modifier. It can modify a verb, a noun, or an adjective. When used as a modifier, the reciprocal relation is subjectoriented. As a verb modifier, it can be pre-verbal or post-verbal as in (52) and (53).

$$
\begin{aligned}
& \text { Orang-orang itu don=sama-sama datang } \\
& \text { person-person that 3PL=RED-together come } \\
& \text { 'The people came together.' }
\end{aligned}
$$



(53) Orang-orang itu don=datang sama-sama person-person that 3PL-come RED-together
'The people came together.'

Pre-verbal and post-verbal adverbial modifiers can also occur with a transitive verb, as in (54) and (55). In these expressions, the adverb sama-sama 'REDtogether' refers to the subject (plural) in mutual relation which acts upon the object; while the object is the patient which is affected by that action.

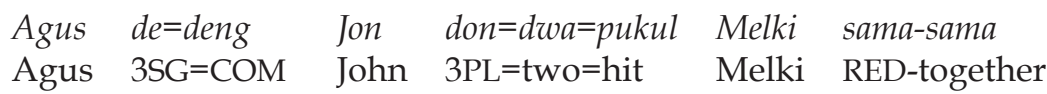
'Agus and John both hit Melki.' $\begin{array}{llllllll}\text { Agus } & d e=d e n g & J o n & \text { don=dwa } & \text { sama-sama } & \text { pukul } & \text { Melki } & \text { dia } \\ \text { Agus } & \text { de=COM } & \text { John } & \text { 3PL=two } & \text { RED-together } & \text { hit } & \text { Melki } & \text { 3SG }\end{array}$

'Agus and John hit Melki together.'

Sama-sama can also be used in modifying subject within a nominal or adjectival predicate, as in (56)-(59). The adverb can be placed in different position, namely between the subject and the predicate or after the predicate.

(56) Don=dwa sama-sama guru

3PL=two RED-together teacher

'They are both teachers.'

(57) Don=dwa guru sama-sama

3PL=two teacher RED-together

'They are both teachers.'

(58) Kam=dwa sama-sama kurus

2PL=two RED-together slim

'Both of you are slim.'

(59) Kam=dwa kurus sama-sama

2PL=two slim RED-together

'You are both slim.'

In (56), sama-sama is a subject-oriented reciprocal, but it also defines the reciprocal meaning with the nominal predicate guru 'teacher'. However, in (57), it is purely a subject-oriented reciprocal. It only defines the mutual relation within the non-singular subject.

In the discourse, in which the background information about the (plural) subject is clear, sama-sama can function as the subject of a nominal predicate as in (60). 
(60) Sama-sama dosen
RED-together lecturer
'(they/we/you) are lecturers'

When the plural subject in the discourse is known to both the speaker and the hearer, sama-sama can be used to modify both the unmarked subject and also the nominal predicate. In (61), dosen 'lecturer' and the sama-sama 'REDtogether' are placed in clause-final position.

$$
\begin{aligned}
& \text {... jadi dosen sama-sama } \\
& \text {... become lecturer RED=together } \\
& \text { '... become lecturer together' }
\end{aligned}
$$

\section{RECIPROCALS AS VALENCE OPERATIONS}

Reciprocals, together with reflexives, passives, causatives, and resultatives, are identified as constructions which trigger valence-changing operations. Valence refers to how many arguments a verb can take. Reciprocals in Papuan Malay can have various effects on valence - whether arguments are increased or reduced in constructions depends on the semantic behaviour of a verb toward its arguments.

\subsection{VALENCE REDUCING OPERATIONS}

A reciprocal in Papuan Malay is expressed by a valence-reducing mechanism in which one of the arguments of a prototypical transitive verb is omitted. A transitive verb is a bi-valent verb which requires two arguments - subject and object - to be present in the surface structure, as in (62).

$$
\begin{aligned}
& \text { (62) Agus de=kejar Yansen dia } \\
& \text { Agus 3SG=chase Yansen 3SG } \\
& \text { 'Agus chased Yansen.' }
\end{aligned}
$$

The prototypical reciprocal construction is a construction in which the valence can be reduced or increased. The reduced valence argument occurs when both the agent and the patient/goal only appear in subject position, as in (63).

$$
\begin{aligned}
& \text { (63) Agus de=deng Yansen don=dwa=baku=kejar } \\
& \text { Agus 3SG=COM Yansen 3PL=two=REC=chase } \\
& \text { 'Agus and Yansen chased each other.' }
\end{aligned}
$$

The construction in (63) only requires a subject argument on the structural level. Semantically, both arguments - subject and object - are still present but they are merged into the syntactic subject.

Note that the causative construction is a valency-increasing operation in which an intransitive verb as in (64a) takes an additional argument. However, 
it can fall into a valency-reducing operation when it is combined within the reciprocal construction. In (64a), the construction is an intransitive sentence. However, it adds another argument to the causative construction as in (64b). Then, it undergoes a valence-reducing operation in which the sentence only has the subject argument in the reciprocal construction as in (64c).

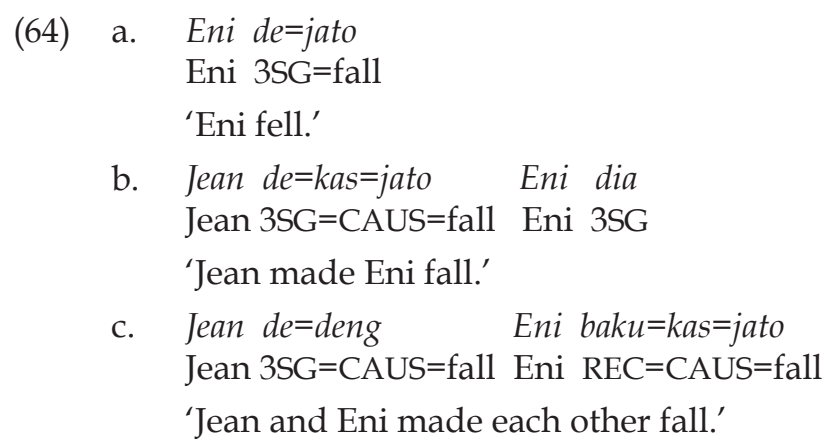

Sentence (64c) shows that the object of the causative construction in (64b) is reduced. Both agent and patient are introduced as the subject when they act in a mutual relation.

\subsection{VALENCE-INCREASING OPERATIONS}

The prototypical reciprocal requires the subject to include the agent and patient/goal, as in (65).
(65) Yunus de=deng Manu don=dwa=baku=dorong
Yunus $35 \mathrm{SG}=\mathrm{COM} \quad$ Manu $3 \mathrm{PL}=\mathrm{two}=\mathrm{REC}=\mathrm{push}$
'Yunus and Manu pushed each other.'

As mentioned above, all alternative constructions of the prototypical reciprocals are valency-increasing operations. Considering alternate constructions from all prototypical reciprocal constructions, the valencyincreasing operations are illustrated in (66), (67), and (68).

(66) Yunus de=baku=dorong deng Manu dia

Yunus $3 S G=R E C=$ push COM Manu 3SG

'Yunus and Manu pushed each other.'

(67) $S a=b a k u=s o d a r a$ deng Manu dia

1SG=REC=sibling COM Manu 3SG

'I and Manu are siblings.'

(68) Orang itu de=baku=taru=lari deng Jon man that $3 \mathrm{SG}=\mathrm{REC}=\mathrm{COMP}=$ run $\mathrm{COM}$ John

'That man and John are competing against each other to run.' 
The combination of reciprocal and causatives can also increase valency, as in (69), (70), and (71).

\begin{tabular}{|c|c|c|c|}
\hline Oran & $\begin{array}{l}\text { itu } \\
\text { that }\end{array}$ & $\begin{array}{l}d e=b i k i n \\
3 S G=\text { make }\end{array}$ & $\begin{array}{l}\text { Agus } \\
\text { Agus }\end{array}$ \\
\hline
\end{tabular}

'That man forced Agus and John to hit each other.' $\begin{array}{lllll}\text { (70) } \quad S a=p u=k a k a & d e=b i k i n & s a=b a k u=\text { taru=lari } & \text { deng } & \text { Andi } \\ \text { 1SG=POSS=brother } & \text { 3SG=make } & \text { 1SG=REC=COMP=run } & \text { COM } & \text { Andi }\end{array}$

'My big brother made Andy and me compete to run against each other.'

$\begin{array}{lll}\text { (71) } \quad \text { De }=\text { baku }=\text { kas }=\text { jato } & \text { deng } & \text { Yosep } \\ \text { 3SG }=\mathrm{REC}=\mathrm{CAU}=\text { fall.down } & \text { COM } & \text { Yosep }\end{array}$

'S/he and Yosep caused each other to fall down.'

The alternate construction requires an object to be realized in its syntactic position, that is to follow the verb. However, the object is realized here as an oblique, following a preposition. Semantically, the object of a preposition indicates that the degree of transitivity is reduced because both agent and patient have the same roles in the mutual relation. Therefore, a reciprocal sentence such as that in (72) is ungrammatical.

$$
\begin{aligned}
& \text { *Yunus de=baku=dorong } \quad \text { Manu dia } \\
& \text { Yunus } 3 \text { SSG=REC=push }
\end{aligned}
$$

\subsection{Retaining GRAMMATICAL RELATIONS OF SUbJECT AND OBJECT}

Papuan Malay also allows a subject and a direct object appear in a reciprocal construction. In the alternate construction, the object is introduced as an oblique argument. In this construction, the object is the direct object. Semantically, both grammatical subject and object refer to the same agent and patient/goal, as in (73) and (74).

(73) Jon de=deng sa tong $=d w a=b a k u=l i a t \quad$ tong $=d w a$ tadi John $3 \mathrm{SG}=\mathrm{COM}$ 1SG $1 \mathrm{PL}=\mathrm{two}=\mathrm{REC}=$ see $1 \mathrm{PL}=\mathrm{two}$ just.now 'John and I saw each other just now.'

$$
\begin{aligned}
& D e n=d w a=d u d u \quad b a k u=t i p u \quad d o n g=d w a \\
& 3 \mathrm{PL}=\mathrm{two}=\text { sit } \quad \mathrm{REC}=\text { lie } \quad 3 \mathrm{PL}=\mathrm{two}
\end{aligned}
$$

'They (two) sat and told a lie to each other.'

Both the subject and the object in (73) and (74) refer to the same agent/ patient participants.

In the satu...satu construction described above, both subject and object are retained by the expression of the repetition of number satu...satu 'one...one'. This follows the basic SVO word order in Papuan Malay, in which the number satu preceding the verb is the subject and the satu following the verb is the object. 
Furthermore, the repetition of the number satu...satu refers to the topicalized participants introduced into the clause initial position, as in (75) and (76).

$\begin{array}{llllll}\text { Jon } & d e=d e n g & \text { Agus itu, satu sayang satu } e \\ \text { John } & \text { 3SG=COM } & \text { Agus that one love one PART }\end{array}$

'As for John and Agus, they love one another.'

(76) Melki de=deng Yunus dong=dwa itu, satu mara satu
Melki 3SG=COM Yunus 3PL=two that, one angry one
'As for Melki and Yunus, they are angry with each other'

\section{CONCLUSION}

Papuan Malay distinguishes prototypical from non-prototypical reciprocals. The prototypical reciprocal construction is the construction which semantically expresses a mutual relation or situation. A mutual situation is defined as a situation in which two participants (A and $B$ ) have the same relation to $A$ and $B$ or B and A. Semantically, A and B act as agent and patient/goal simultaneously (see Haspelmath 2007). Papuan Malay has three types of reciprocals: lexical, the baku construction, and the satu...satu construction. In terms of the argument structure, prototypical reciprocals allow the subject argument to represent both the semantic agent and the patient/goal. The mutual relation of the agent and patient/goal is established in the subject argument. The alternate reciprocal construction allows the subject and object in the syntactic structure to represent both the agent and patient/goal. However, the object argument is expressed as an oblique argument. The oblique argument reduces the degree of transitivity of the verb to accommodate the semantic expression of mutual relation.

Papuan Malay also allows various constructions which are called reciprocal-like constructions. These constructions are not like prototypical reciprocals structurally, but they still show mutual relations semantically. Such reciprocal-like constructions can occur within verbal, nominal, and adverbial predicates. The subject argument is always a plural subject which shows a mutual relation between the agent and patient/goal.

The wide ranges of variations affect the valency of the verb. Reciprocal constructions can trigger valence-reducing or valence-increasing operations. The prototypical reciprocals basically trigger valence reducing operations. In contrast, the alternate reciprocal construction triggers a valence-increasing operation. There are also constructions in which the argument structure of the subject and the object is retained. 


$\begin{array}{ll}\text { ABBREVIATIONS } \\ \text { ACT } & \text { Active } \\ \text { APPL } & \text { Applicative } \\ \text { AVP } & \text { Agent-Verb-Patient } \\ \text { CAUS } & \text { Causative } \\ \text { COM } & \text { Comitative } \\ \text { COMP } & \text { Competitive } \\ \text { DU } & \text { Dual } \\ \text { FOC } & \text { Focus } \\ \text { IMP } & \text { Imperative } \\ \text { LOC } & \text { Locative } \\ \text { NEG } & \text { Negative } \\ \text { OBJ } & \text { Object } \\ \text { PART } & \text { Particle } \\ \text { PL } & \text { Plural } \\ \text { POSS } & \text { Possessive } \\ \text { REC } & \text { Reciprocal } \\ \text { RED } & \text { Reduplicative } \\ \text { REFL } & \text { Reflexive } \\ \text { REL } & \text { Relative clause } \\ \text { SG } & \text { Singular } \\ \text { SUBJ } & \text { Subject } \\ \text { SV } & \text { Subject-Verb } \\ & \end{array}$

\section{REFERENCES}

Asudeh, Ash. 1998. "Anaphora and argument structure; Topics in the syntax and semantics of reflexives and reciprocals". MPhil thesis, University of Edinburgh.

Conroy, John. 2013. “The informal economy in Monsoon Asia and Melanesia; West New Guinea and the Malay world", Crawford School Working Paper Vol. 13-04. Canberra: Australian National University. [Retrievable: https:/ / econpapers.repec.org/paper/eencrwfrp/1304.htm.]

Donohue, Mark. 2011. "Papuan Malay of New Guinea; Melanesian influence on verb and clause structure", in: Claire Lefebvre (ed.), Creoles, their substrates, and language typology, pp. 413-435. Amsterdam: John Benjamins.

Donohue, Mark and Yusuf Sawaki. 2007. "Papuan Malay pronominals; Forms and functions", Oceanic Linguistics 46(1): 253-276.

Evans, Nicholas. 2006. "Complex events, propositional overlay, and the special status of reciprocal clauses", in: Sally Rice and John Newman (eds), Empirical and experimental methods in cognitive/functional research. Stanford, CA: CSLI Publications.

Evans, Nicholas. 2008. "Reciprocal constructions; Towards a structural typology", in: Ekkehard König and Voker Gast (eds), Reciprocals and reflexives; Theoretical and typological explorations, pp. 33-104. Berlin: Mouton de Gruyter.

Evans, Nicholas, Alice Gaby, Stephen C. Levinson, and Asifa Majib (eds). 2011. Reciprocals and semantic typology. Amsterdam: John Benjamins. 
Gau, Sukardi. 2011. “Menjejaki bahasa Melayu Maluku di Papua; Kerangka pengenalan", Jurnal Elektronik Jabatan Bahasa dan Kebudayaan Melayu Jilid 3: $21-40$.

Haga, Antonie. 1884. Nederlandsch Nieuw Guinea en de Papoesche Eilanden; Historiche bijdrage, $\pm 1500-1883$. Batavia: W. Bruining, 's-Hage: Martinus Nijhoff.

Haspelmath, Martin. 2007. "Further remarks on reciprocal constructions", in: Vladimir P. Nedjalkov (ed.), Reciprocal constructions, pp. 2087-2115. 5 vols. Amsterdam: John Benjamins.

Hurst, Peter. 2006. The syntax of the Malagasy reciprocal construction; An LFG account. Stanford, CA: CSLI Publications.

Kluge, Angela. 2014. A grammar of Papuan Malay. PhD thesis, Leiden University. [LOT Dissertation Series.]

König, Ekkehard and Voker Gast (eds). 2008. “Reciprocality and reflexivity description, typology, and theory”, in: Ekkehard König and Voker Gast (eds), Reciprocals and reflexives; Theoretical and typological explorations, pp. 1-32. Berlin: Mouton de Gruyter.

Litamahuputty, B.H.J. 2012. Ternate Malay; Grammar and texts. PhD thesis, Leiden University. [LOT Dissertation Series.]

Minde, Don van. 1997. Malayu Ambong; Phonology, moprhology, syntax. Leiden: Research School CNWS.

Nedjalkov, Vladimir (ed.). 2007. Typology of reciprocal constructions. Amsterdam: John Benjamins.

Nordlinger, Rachel. 2008. "Reciprocals in Murrinh-Patha”. [University of Melbourne.]

Paauw, Scott H. 2008. The Malay contact varieties of Eastern Indonesia; A typological comparison. PhD thesis, The State University of New York, Buffalo.

Prentice, David J. 1994. "Manado Malay; Product and agent of language change", in: Thomas E. Dutton and Darrell T. Tryon (eds), Language contact and change in the Austronesian world (Trends in Linguistics; Studies and Monographs 77), pp. 411-441. Berlin/New York, NY: Mouton de Gruyter.

Rutherford, Danilyn. 2005. "Frontiers of the lingua franca; Ideologies of the linguistic contact zone in Dutch New Guinea", Ethnos Vol. 70. No. 3: 387412. [Retrieved from: http:/ / dx.doi.org/10.1080/00141840500294490; last accessed on 18-12-2013.]

Sawaki, Yusuf. 2016. A grammar of Wooi, an Austronesian language of Yapen Island, Western New Guinea. PhD thesis, Australian National University, Canberra.

Sawaki, Yusuf and Sara Karubaba. 2012. "Where do person/number marking and inclusory pronominals in Papuan Malay come from?". [Paper, The Twelfth ICAL 2012, Denpasar, 2-6 July.]

Seiler, W. 1983. The lost Malay language of Papua New Guinea. Canberra: Australian National University.

Stark, Ken and Kyle Latinis. 1996. “The response of early Ambonese foragers tot he Maluku spice trade; The archaeological evidence", Cakalele Vol. 7: 51-67. 
Steinhauer, Hein. 1983. Notes on the Malay of Kupang (Timor). Leiden: University of Leiden.

Velzen, Paul van. 1995. "Some notes on the variety of Malay used in Serui and vicinity", in: Connie Baak, Mary Bakker, and Dick van der Meij (eds), Tales from a concave world; Liber amicorum Bert Voorhoeve, pp. 311-343. Leiden: Department of Languages and Cultures of Southeast Asia and Oceania, Leiden University.

Wantalangi, Maxi. 1993. "The Menadonese grammar". MA thesis, La Trobe University, Bundoora. 